\title{
APRENDIZAGEM POR CHAT VIA AVA: RELATO DE UMA EXPERIÊNCIA DE ENSINO DE FILOSOFIA
}

CURITIBA/PR MAIO/2018

\author{
Alvino Moser - UNINTER - alvino.m@uninter.com \\ Neliva Terezinha Tessaro - UNINTER - neliva.t@uninter.com \\ Nelson Pereira Castanheira - UNINTER - nelson.c@uninter.com
}

Tipo: Relato de Experiência Inovadora (EI)

Categoria: Métodos e Tecnologias

Setor Educacional: EDUCAÇÃO SUPERIOR

\begin{abstract}
RESUMO
Nesta comunicação apresentamos uma metodologia de ensino da Filosofia em que os estudantes do curso de Ciências Contábeis deveriam estudar vários filósofos, mediante a interação e colaboração por chat, em grupo. Essas interações ocorreram via AVA. Os resultados indicam que os alunos apreciam a aprendizagem em colaboração. E também mostram que o ensino de Filosofia se torna mais produtivo se o docente se dispõe a aprender com os alunos, pois, Quem ensina, aprende ao ensinar e quem aprende ensina ao aprender.
\end{abstract}

Palavras-chave: Ensino da filosofia; aprendizagem sociointeracionista; aprendizagem colaborativa 


\section{INTRODUÇÃO}

Sem dúvida, à primeira vista, o título deste artigo deve parecer estranho aos professores de Filosofia. Não somente aos professores que ensinam Filosofia pelo método tradicional expositivo, mas até para muitos que tratam do ensino por rede, mas que têm uma perspectiva tradicional dessa disciplina. Foi o que aconteceu em uma mesa redonda durante um congresso dedicado às Redes Sociais Aplicadas à Educação. Quando os autores destas linhas sugeriram que estavam tentando ensinar Filosofia por meio das redes sociais, foi respondido que a Filosofia era reflexão. Ora, sabemos que Sócrates, Platão, os estoicos e os epicuristas dialogavam com seus discípulos. Portanto, pode-se aplicar ao ensino da Filosofia o sócio-interacionismo de Vygotsky, segundo o qual a aprendizagem se dá pela mediação social. Para Vygotsky (2015), a interação tem uma função central no processo de internalização. No livro A Formação Social da Mente: O Desenvolvimento dos Processos Psicológicos Superiores, é dito que "o caminho do objeto até a criança e desta até o objeto passa por outra pessoa". Há assim interação com a outra, mediada pela linguagem.

Em suma, a linguagem constitui o sistema de mediação simbólica que funciona como instrumento de comunicação, planejamento e autorregulação. É justamente pela sua função comunicativa que o indivíduo se apropria do mundo externo, pois é pela comunicação estabelecida na interação que ocorrem "negociações", reinterpretações das informações, dos conceitos e dos significados. A atividade mental é exclusivamente humana e é resultante da aprendizagem social, da interiorização da cultura e das relações sociais.

\section{APRENDIZAGEM SOCIAL}

À interação com o outro ou em seguida à interação mediada pela linguagem ou pelos sistemas semióticos, segue-se a interiorização das informações que se tornam conhecimentos conscientes.

Essa interiorização não é simplesmente a transferência de uma atividade externa para um plano interno, mas é o processo no qual esse interno é formado. Ela constitui um processo que não segue um curso único, universal e independente do desenvolvimento cultural. O que nós interiorizamos são os modos históricos e culturalmente organizados de operar com as informações do meio. (LUCCI, 2013).

Segundo Vygotsky (2015), o primeiro contato da criança com novas atividades, habilidades ou informações deve ser a participação de um adulto. Ao internalizar um 
procedimento, a criança "se apropria" dele, tornando-o voluntário e independente. Nas palavras de Rego (2001), em síntese, nessa abordagem, o sujeito produtor de conhecimento não é um mero receptáculo que absorve e contempla o real nem o portador de verdades oriundas de um plano ideal; pelo contrário, é um sujeito ativo que em sua relação com o mundo, com seu objeto de estudo, reconstrói (no seu pensamento) este mundo. O conhecimento envolve sempre um fazer, um atuar do homem.

Isto nos leva a considerar a importância do meio social em que se produza mediação. Wenger (2008, p. 3) não se fixa nos meios, mas na interação social no contexto da aprendizagem. "Nossas instituições se baseiam largamente na pressuposição de que a aprendizagem é um processo individual, do começo ao fim, que é separado do resto de nossas atividades, e que é resultado do ensino".

Trata-se de uma explicação ou exposição do significado numa estrutura social, num meio social, tão bem a gosto dos vygotskyanos. A aprendizagem se processa pela pertença à comunidade, pelo aprender na prática com os membros da comunidade participando e fazendo suas contribuições. Aprende com os seus pares, apelando para o professor apenas quando precisa de orientação. Quando faz a experiência de procurar as informações para conhecer adquire o verdadeiro significado do aprender: não precisa que se transmita o conteúdo. Por isso, é necessário alargar a aprendizagem e considerar o seu caráter social.

Uma teoria social da aprendizagem é, portanto, não uma empresa exclusivamente acadêmica. Enquanto esta perspectiva pode na verdade informar nossas investigações acadêmicas, é também relevante para nossas ações cotidianas, nossas políticas, e para os nossos projetos organizacional técnico, e o sistema educacional. Um novo quadro referencial a respeito da aprendizagem é de valor não apenas para os teóricos, mas também para todos nós - professores, estudantes, pais, jovens. (WENGER, 2008, p. 9).

Portanto, a aprendizagem individual se processa não apenas com esforço da pessoa isolada, mas o contexto das redes que constituem uma comunidade. Em geral, a aprendizagem cognitiva é vista como uma apropriação de "conteúdo", sendo este o que mais importa. Os meios de ensinar se transformaram desde o ensino oral que se baseava na fala do professor. Assim, passaram da fala para o texto didático, e agora estudantes e alunos têm à disposição o acesso a WEB 1.0, 2.0, 3.0 (PRENSKY, 2010) que permite que os estudantes possam aprender no cyber espaço. (LEVY, 2010). Sua aprendizagem não pode apenas estar centralizada nas aulas em que o professor dita as aulas. Contudo, alerta muito bem Wenger (2008, p. 37): 
Há muitas diferentes espécies de teorias da aprendizagem. Cada uma enfatiza diferentes aspectos da aprendizagem, e cada uma delas é, portanto, útil para os diversos objetivos que almejam. Portanto, é preciso que em relação aos alunos os professores deixem-nos:

a) achar e seguir as suas paixões; usar todas as tecnologias disponíveis para procurar e encontrar informação;

b) responder perguntas e compartilhar seus pensamentos e opiniões;

c) aprender quando motivados (por exemplo, por meio de games);

d) criar apresentações em texto e multimídia.

Esta pedagogia requer que os docentes façam o que eles fazem de melhor, por meio de perguntas corretas: orientar os alunos, contextualizar o material, explicar individualmente, exigir o rigor nas tarefas para garantir a qualidade. (WENGER, 2008). Portanto, é uma pedagogia que se assemelha à maiêutica socrática e ao método de inquérito preconizado por Neil Postman e Charles Weingartner (1974). Estes propunham que o professor em aula apenas fizesse três afirmações e 16 perguntas relevantes. Mas, diferentemente da postura socrático-platônica, não há o diálogo entre os mestres e os discípulos: os alunos buscam por si mesmos na Internet, nos livros ou semelhantes e discutem em grupo, apelando para o professor mediador apenas em caso de necessidade.

O método socrático da interrogação que pretende conduzir o aluno a seu próprio saber, é de fato de um amestrador de cavalos. 'Ele comanda as evoluções, as marchas e contramarchas. De sua parte, conserva o repouso e a dignidade do comando durante o manejo do espírito que está dirigindo. De desvios em desvios, o espírito chega a um fim que não havia entrevisto quando da partida. Ele se espanta, se volta, percebe seu guia, o espanto se transforma em admiração e o embrutece. $O$ aluno sente que, sozinho e abandonado a si mesmo, ele não teria seguido essa rota'. (JACOTOT, apud RANCIÈRE, 2007).

É uma forma disfarçada de ensino bancário e a epistemologia que o fundamenta é a que Popper denomina de teoria do balde mental. "De acordo com essa concepção, assim, nossa mente se assemelha a uma vasilha - uma espécie de balde - em que percepções e conhecimento se acumulam". (POPPER, 1975).

Na concepção 'bancária' que estamos criticando, para a qual educação é o ato de depositar, de transferir, de transmitir valores e conhecimentos, não se verifica nem pode verificar-se esta superação. Pelo contrário, refletindo a sociedade opressora, sendo 
dimensão da 'cultura do silêncio' a 'educação' 'bancária' mantém e estimula a contradição. (FREIRE, 1997).

Continuando sua exposição, Prensky (2010) se refere a uma objeção que os professores geralmente fazem: e como fica o currículo? Responde dizendo que os currículos expõem o que se deve aprender, mas não como aprender. Por conseguinte, fica claro que não temos por escopo nesta pesquisa discutir o conteúdo dos currículos, que em muitos casos estão completamente fora de contexto e desatualizados, pois que são elaborados em geral por especialistas de gabinete e até por políticos.

O que importa é que o professor seja mediador e que os alunos possam ser seus professores aprendendo por si mesmos e com seus colegas. Compete ao professor ser o orientador e guia de tarefas. Fixará os objetivos e as finalidades das tarefas, como hábil questionador. Não basta fazer perguntas se essas não têm interesse para os alunos, donde a necessidade de saber como motivá-los e mobilizá-los para 0 autoestudo. Para isso deverá aprender sempre novos designs de ensino, evitando a repetição e a monotonia.

Sobretudo, a pedagogia da parceria exige uma nova aprendizagem no manejo de classe e da disciplina, pois é necessário que abandone o controle total, deixando tempo aos alunos para pesquisarem e resolverem as questões e tarefas propostas. Sua intervenção será sempre como mediadora, evitando fornecer aos alunos respostas prontas, retirando-Ihes o prazer da descoberta.

\section{APRENDIZAGEM POR CHAT EM AMBIENTE VIRTUAL DE APRENDIZAGEM}

Resolvemos aplicar ao ensino da Filosofia os pressupostos citados e considerando 0 conectivismo como uma das teorias mais adaptada e conveniente para a geração digital. E, por outro lado, o Centro Universitário Internacional Uninter disponibiliza aos alunos e professores o Ambiente Virtual de Aprendizagem - AVA Univirtus, onde há a possibilidade de se criar grupos nos quais os alunos podem se comunicar por meio de chats, tanto de maneira síncrona como assíncrona, recurso este sobejamente conhecido e aplicado.

O objetivo da pesquisa foi verificar como este recurso, chat em grupo, era percebido e aceito por estudantes do ensino superior que estudavam Filosofia como disciplina complementar no Curso de Ciências Contábeis. 
Em seguida, analisar se esse recurso convinha à aprendizagem dessa disciplina que, em geral, é relegada a um segundo plano, por não estudar temas específicos de sua futura profissão. Contou-se com 21 alunos do $7^{0}$ período, sendo 7 do gênero masculino e 14 do gênero feminino, divididos em 6 grupos de até 4 alunos.

O trabalho consistiu em uma pesquisa bibliográfica sobre um filósofo para cada grupo, com utilização do chat do grupo para os comentários e discussões. O objeto de pesquisa foi assim distribuído: Grupo 1 - Platão; Grupo 2 - Aristóteles; Grupo 3 Pitágoras; Grupo 4 - Epicuro; Grupo 5 - Zygmunt Bauman; Grupo 6 - Diógenes.

Foi-Ihes explicado que a avaliação constava de três fases: 1. As participações nos chats; 2. A postagem do trabalho; 3. E a exposição em sala de aula.

Para realizar o trabalho, os estudantes tiveram à sua disposição um período de aula. Mas, como as apresentações foram nas aulas seguintes, tiveram oportunidade de se comunicar de maneira assíncrona. Desta forma poderiam interagir com os colegas do grupo durante toda a semana.

As interações foram salvas e assim divididas: Grupo 1 - 4 participantes - 7 posts; Grupo 2 - 4 participantes - 14 posts; Grupo 3 - 4 participantes - 7 posts; Grupo $4-2$ participantes - 13 posts; Grupo $5-4$ participantes -21 posts; Grupo $6-3$ participantes -29 posts.

\section{ANÁLISE DA APRENDIZAGEM}

A análise dos posts mostra como os alunos leem os filósofos, pois não tiveram aulas ou preleções que dirigissem suas leituras. Os estudantes tiveram uma leitura própria, de maneira livre e autônoma. Ora, é esse o objetivo das aulas de Filosofia, que os alunos construam seu próprio conhecimento.

Cabe ao docente, como o afirma Prensky (2010), "Avaliar as soluções respostas e soluções dos alunos examinando a qualidade e o rigor; contextualização. E assim o aluno possa refinar e melhorar as respostas, adicionando rigor, contexto e qualidade". Obteve-se os seguintes dados na pesquisa:

\section{a) GRUPO 1: PLATÃO}

Os estudantes postaram: Boa Tarde Pessoal. Muito interessantes as ideias do filósofo Platão, tendo em vista que suas principais ideias eram voltadas para o conhecimento e 
educação, ou seja, o que estamos em busca hoje, se estamos todo dia aqui na faculdade é porque acreditamos que com conhecimento teremos um crescimento e amadurecimento tanto ético como moral. Platão contribui muito com suas ideias para a educação, ele acreditava que a conversação e o debate eram a forma de obter o conhecimento, que os alunos deveriam descobrir as coisas mediante os obstáculos impostos pela vida. Isso se vê até hoje e aprendemos muito na teoria, mas é na pratica e conforme aparecem os problemas que vamos aprendendo como nos comportarmos.

Há nesse comentário uma aplicação das ideias de Platão ao dia a dia de cada aluno. Ficam na estratosfera das abstrações que torna a filosofia chata.

O bem-pensar clássico de fato, baseia-se unicamente na cultura livresca. Se fosse muito instruído, o que está bem longe de ser o caso, poderia dizer-se que o engenheiro social que leva os mais diversos nomes, perito, especialista, consultor... é doctus cum libro. (MAFFESOLI, 2009).

E prosseguem os posts: Platão construiu o seu conhecimento através do diálogo e troca de experiências com os seus amigos e mestres, como por exemplo, Sócrates. E acredito eu que por experiência própria é que Platão dá a devida relevância ao método de conversação para a construção de um pensamento.

Acredito que se estes Filósofos não tivessem dado sua contribuição para a humanidade tudo seria muito cientifico e o homem não conheceria a essência do pensamento.

\section{b) GRUPO 2: ARISTÓTELES}

No início assinalam os dados biográficos de Aristóteles. Esse grupo assinala alguns pensamentos do Estagirita e tecem comentários sobre sua doutrina e seus pensamentos. Antes comentam o estilo do filósofo: "A primeira qualidade do estilo é a clareza". A seguir, selecionam alguns pensamentos: A educação tem raízes amargas, mas os frutos são doces. O valor final da vida depende mais da consciência e do poder de contemplação, que da mera sobrevivência. Prudência é não dizer tudo o que se pensa, mas pensar tudo o que se pensa.

Esse grupo salienta o valor da educação que, segundo Aristóteles, deve ter raízes amargas, o que significa que a educação deve exigir esforço por parte do aluno.

Um erro da renovação pedagógica foi a convicção de ser preciso, de início, seduzir os alunos para que, em seguida, se interessassem; motivá-los num primeiro momento, com 
diversos engana bobo, para, num segundo momento, eles se aplicarem ao estudo. Todos se puseram, para fisgar os alunos como se pescam peixes - o que chamo pedagogia do anzol. Para mim, trata-se da ilusão pedagógica por excelência. Tenta-se "motivar" o aluno, abandonando a pedagogia do esforço em prol da pedagogia da brincadeira ou do "desapertar". Disciplina nenhuma é apaixonante à primeira vista e não conheço meio algum de fazer uma criança estudar, que não exija um mínimo de autoridade. (FERRY; LAIGNEL-LAVASTINE, 2012). E continua afirmando que esta é a pedagogia do trabalho e é a síntese entre a pedagogia do jogo e a pedagogia do amestramento. Essas ideias foram compartilhadas pelo grupo 1.

\section{c) GRUPO 3: PITÁGORAS}

Sobre Pitágoras o grupo destacou a teoria da metempsicose ou da transmigração das almas e a teoria pitagórica sobre os números. Essas teorias foram discutidas pela equipe de maneira interessante, como se pode ver pela transcrição dos diálogos: Acreditavam (os pitagóricos) na metempsicose e na reencarnação, esta crença cresceu com as religiões populares e praticavam um culto "Orfismo" onde diziam da existência de uma alma imortal que após a morte do indivíduo, podia encarnar em outra pessoa e a partir daí continuar o ciclo de vida. Educai as crianças de não será preciso punir os homens lá na frente. Ajuda teus semelhantes a levantar a carga, mas não a carregues. Isso era conduzido pelo deus Dionizio e Pitágoras dizia que como tudo era conduzido pelos números, somente eles poderiam liberar a alma para partir para o outro corpo. A seguir, em sua discussão, as interações mostram que as ideias de Pitágoras são difíceis para serem aceitas pelos estudantes.

\section{d) GRUPO 4: EPICURO}

Este grupo era constituído por 2 estudantes. Comentaram: Epicuro foi um filósofo grego, conhecido como Epicuro de Samos, pois nasceu na llha de Samos, em 341 a.C. e morreu em Atenas, por volta de 271 e 270 a.C. Em Samos, ele chegou a ouvir o filósofo Pânfilo, porém não o agradou, então muito jovem, seu pai o mandou para Téos, na costa da Ásia Menor, onde com Nausífanes de Téos, discípulo de Demócrito, teve contato com a teoria atomista. Epicuro teve uma vida marcada pela dor, pois sofria de cálculo 'renal, mas morreu cercado de amigos e discípulos, marcado por uma vida de serenidade, doçura e asceticismo.

Aqui não foram além do que se encontra nos sites. Não houve interação. 
Este grupo teve como tarefa assistir e comentar dois vídeos em que Bauman fala sobre a comunicação e a ética na pós-modernidade. As discussões foram interessantes. Interessantíssimo. As pessoas não querem saber como são as outras. $O$ respeito está sumindo. Mas o importante é que está tendo protesto. E eu imagino que isso poderá mudar em algo. Acho que as pessoas hoje em dia são muito egoístas, pensam muito em si próprias e esquecem-se do resto do mundo... Muitas vezes as pessoas esquecem-se dos outros, devido a tecnologia que nos rodeia, pois até mesmo para conversar com 0 colega do lado se usa a tecnologia para mandar mensagens, ao invés de conversar pessoalmente...e isso acaba levando as pessoas a sua própria solidão.

Zygmunt Bauman relata neste vídeo a troca que fazemos para ter as coisas, no caso segurança e liberdade, que sempre será preciso abrir mão de uma para ter mais a outra e vice-versa, assim como tudo na vida. Também fala sobre as formas de buscarmos a felicidade, que poderá ser influenciada pelo nosso destino, mas também pelo caráter que é algo único em cada um, mas que pode ser melhorado. $O$ destino te dá as opções, mas seu caráter irá definir o caminho a ser seguido. Logo, define-se que não há receita para a felicidade.

Os comentários falam por si. E os seguintes debatem as mesmas ideias.

\section{f) GRUPO 6: DIÓGENES}

As interações sobre Diógenes mostraram que os ensinamentos da escola cínica têm eco entre os jovens da atualidade, como se vê pelos posts transcritos:

- Achei interessante, pois ele era contra o matrimonio.

- Sim, é importante colocarmos que ele vivia em um barril junto com os cachorros. E desprezava os poderosos e as convenções sociais. Este também foi fundador da filosofia cínica.

- Lembrando que para que o indivíduo fosse realmente feliz, ele precisava viver de uma forma natural, sem conviver com a sociedade e ter qualquer vínculo afetivo.

\section{CONCLUSÕES}

Esses diálogos mostram que não é fácil traduzir a filosofia para o dia a dia dos estudantes. A recepção que os mesmos fazem das doutrinas são altamente pedagógicas e servirão de orientação para as aulas de Filosofia, se os docentes, como o prega Paulo Freire, tiverem a capacidade e a humildade de aprenderem com seus alunos, no diálogo. É neste sentido que ensinar não é transferir conhecimentos, conteúdos nem formar; é ação pela qual um sujeito criador dá forma, estilo ou alma a 
um corpo indeciso e acomodado. Não há docência sem discência, as duas se explicam e seus sujeitos, apesar das diferenças que os conotam, não se reduzem à condição de objeto, um do outro. Quem ensina aprende ao ensinar e quem aprende ensina ao aprender. (FREIRE, 1997).

\section{REFERÊNCIAS}

FERRY, LUc; LAIGNEL-LAVASTINE, Alexandra. 0 anticonformista - uma autobiografia intelectual. Rio de Janeiro: Difel, 2012.

FREIRE, Paulo. Pedagogia da autonomia. São Paulo: Paz e Terra, 1997.

JACOTOT, Joseph. Enseinement naturel. Droit et philosophie panécastique. Paris, 1838, p. 41 apud RANCIÈRE, 2002.

LEVY, Pierre. Cibercultura. São Paulo: Editora 34, 2010.

LUCCI, Marcos Antônio. A proposta de Vygotsky: a psicologia sócio-histórica. Profesorado. Revista de currículum y formación del profesorado, p. 1-11, 2006. Disponível em: . Acesso em: 19 mar. 2017.

MAFFESOLI, Michel. A república dos bons sentimentos. São Paulo: Iluminuras, 2009. POPPER, Karl Raimund. Conhecimento objetivo. São Paulo: EDUSP, 1975.

POSTMAN, Neil e WEINGARTNER, Charles. Contestação - nova fórmula de ensino. Rio de Janeiro: Expressão e Cultura, 1974.

PRENSKY, Marc. Teaching digital natives. Partnering for real learning. Thousand Oaks, California: Corwin, A Sage Company, 2010.

RANCIÈRE, Jacques. O mestre ignorante: cinco lições sobre a emancipação intelectual. Belo Horizonte: Autêntica Editora, 2007.

REGO, Teresa Cristina. Vygotsky: uma perspectiva histórico-cultural da educação. 12. ed. Petrópolis: Rio de Janeiro: Vozes, 2001.

VYGOTSKY, L. S. A formação social da mente: o desenvolvimento dos processos psicológicos superiores. 5. ed. São Paulo: Martins Fontes, 2015. 